\title{
NOTES ON THE PLANTS OF THE DOUGLAS PROVINCIAL PARK SEEPAGE AREAS
}

S. M. LAMONT, Saskatchewan Museum of Natural History, Wascana Park Regina, Saskatchewan S4P 3V7

EDITOR'S NOTE: Douglas Provincial Park is located on the east shore of Lake Diefenbaker, about $13 \mathrm{Km}$ south of Elbow, Saskatchewan on number 19 highway.

One of the several purposes served by Douglas Provincial Park is to preserve an area of unique vegetation associations. To a nature lover it is the wildlife, and unique features of land and vegetation that are attractions within this park. The author found the lakeshore seepage areas to be of special interest. An attempt is therefore made to describe this feature of Douglas Provincial Park so that others may be lured into exploring them and share the beauty of these small areas. The fascination of the springs was due to the presence of showy wildflowers, plants outside what is considered their normal range, and plants rare in Saskatchewan.

Originally the seepage areas were found at the top of the bank of the South Saskatchewan River, and no doubt their courses down the slope were marked by species of plants that are not found at their source. However the building of Gardiner Dam and the resulting reservoir have flooded all but the origin of the streams. Trees such as Manitoba maple Acer negundo, green ash Fraxinus pennsy/vanica, American elm Ulmus americana, and perhaps eastern cottonwood Populus deltoides may have grown on the slopes, but are not found within the park area, with the exception of maple. There may be areas along the South Saskatchewan and Qu'Appelle river valleys supporting vegetation similar to that which was found in the now floode ravines that drained the seepage fror these sites into the South Saska chewan River. That will never $b$ known to those of us who were no lucky enough to have seen the are before.

The ground in the seepage areas generally either gently sloped hummocky. Hummocky terrain usually associated with the wette areas, with standing water in th hollows. Seepage varies from fres water to saline. The vegetatio changes with the salinity as well a with the amount of water presen Some of the seepage areas are situate high enough that the water table drop below the ground surface before th end of the summer. This allows the so to dry somewhat. In these area grasses and rushes dominate, wherea in areas that remain wet sedges tend to be more abundant.

Scattered throughout much of th wetter areas are clumps of hoar willow Salix candida, and swamp birc Betula glandulifera. Both are specie found most commonly in swamps an bogs of the northern forest. Around th margins of the wetter areas water bircl $B$. occidentalis grows and there ar various other willows such as thi common beaked willow S. bebbiani and sandbar willow $S$. interior, and the less frequent autumn willow serissima.

In the continuously wet, spring areas there are a variety of sedges tha are found only in this type of habitat These include golden sedge Cares 


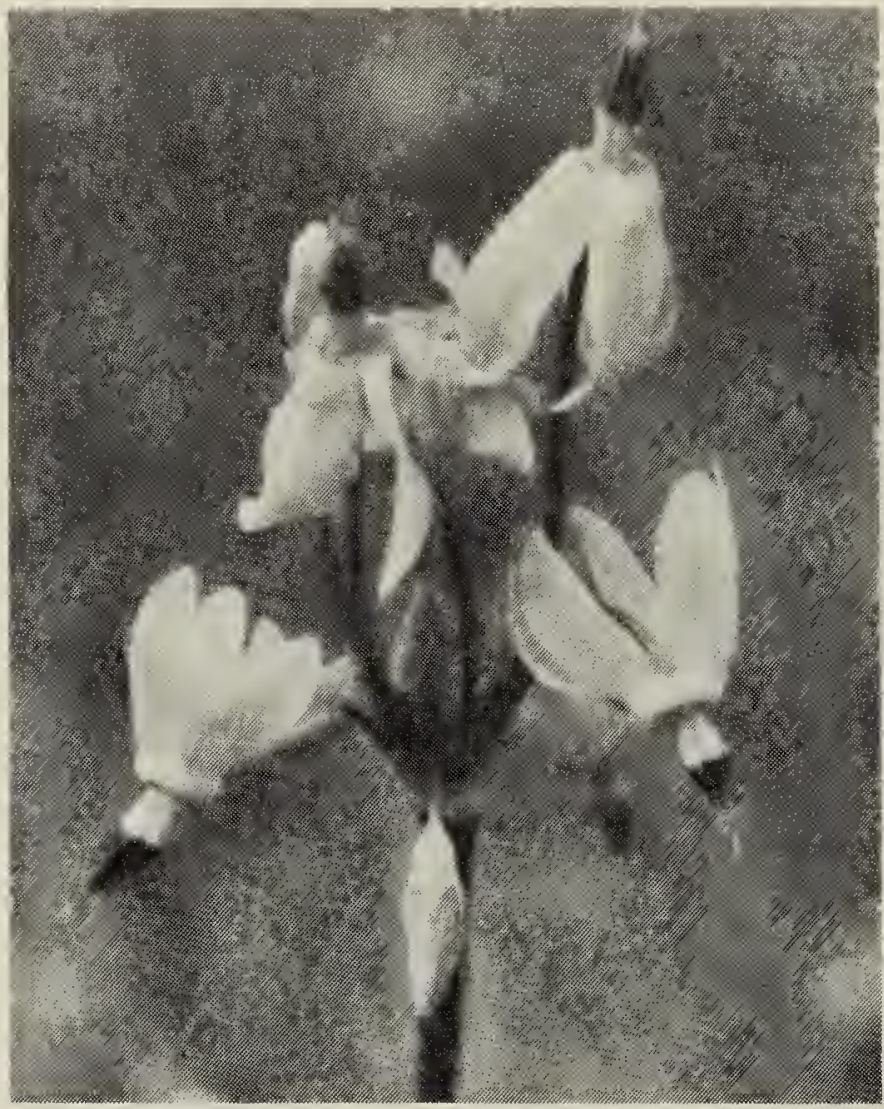

Saline shooting-star

S. M. Lamont

include many familiar to prairie and parkland dwellers - early blue violet Viola adunca, common tall sunflower Helianthus nuttallii, small-leaved everlasting Antennaria parvifolia, numerous asters Aster spp. and goldenrods Solidago spp. Some of the seepage areas have a few pinkflowered wintergreen Pyrola asarifolia blooming on the hummocks.

In more saline areas northern reed grass Calamagrostis inexpansa and alkali bluegrass Poa juncifolia are frequently found. Where the surface does not remain wet and salinity is high, little bluestem Andropogon scoparius is a grass that can be recognized from a distance in autumn and spring because of the distinctive rusty orange of the dry stems and leaves. Scirpus-like sedge Carex scirpoedea var. scirpiformis and greenish sedge $C$. viridula $=C$. oederi also indicate saline conditions.

Saline shooting-star Dodecatheon pauciflora is a familiar prairie flower of saline areas. So is mealy primrose Primula incana with its clusters of small lilac flowers with yellow centers on a stem above a rosette of leaves distinguished by their white, mealy underside. As summer advances white or smooth camas Zygadenus elegans blooms. The common name is slightly misleading as the star-shaped flowers are really a greenish color. Blue-eyed grass Sisyrinchium montanum blooms most abundantly in the more saline areas.

Near what is now the lakeshore the seepage water is quite fresh in the lower parts, and some flow may be detected. Larger seepage areas may have cattails Typha latifolia, common great bulrush Scirpus validus, threesquare $S$. americanus and small-fruited bulrush S. microcarpus. Early summer flowers include narrow-leaved waterplantain Alisma gramineum with its three pink-tinged petals and tufted loosestrife Lysimachia thyrsiflora, bearing clusters of tiny, bright yellow flowers at its leaf bases.

Although the grasses, sedges and shrubs of the Douglas Provincial Park seepage areas are of interest to the botanist, for most people it is the plants with showy or unusual flowers that attract attention. These seepage areas support a variety of wildflowers to be sought out during different seasons and are an added attraction to all the other features that Douglas Provincial Park has to offer.

ACKNOWLEDGEMENTS: I would like to thank John Hudson for looking at the specimens of sedges collected at the springs, and George Ledingham for verification of the Loesel's twayblade. Also thanks go to John Storer and Wayne Harris for critical reading of the manuscript. The information for this article was gathered during temporary employment with the Museum of Natural History in Regina.

'HUDSON, J. H. 1978. Carex of Saskatchewan. Buffalo Press, Saskatoon. 